\title{
WHĀEA BETTY WARK: FROM UNCERTAIN BEGINNINGS TO HONOURED COMMUNITY WORKER ${ }^{1}$
}

\author{
HELENE CONNOR \\ Unitec, Auckland
}

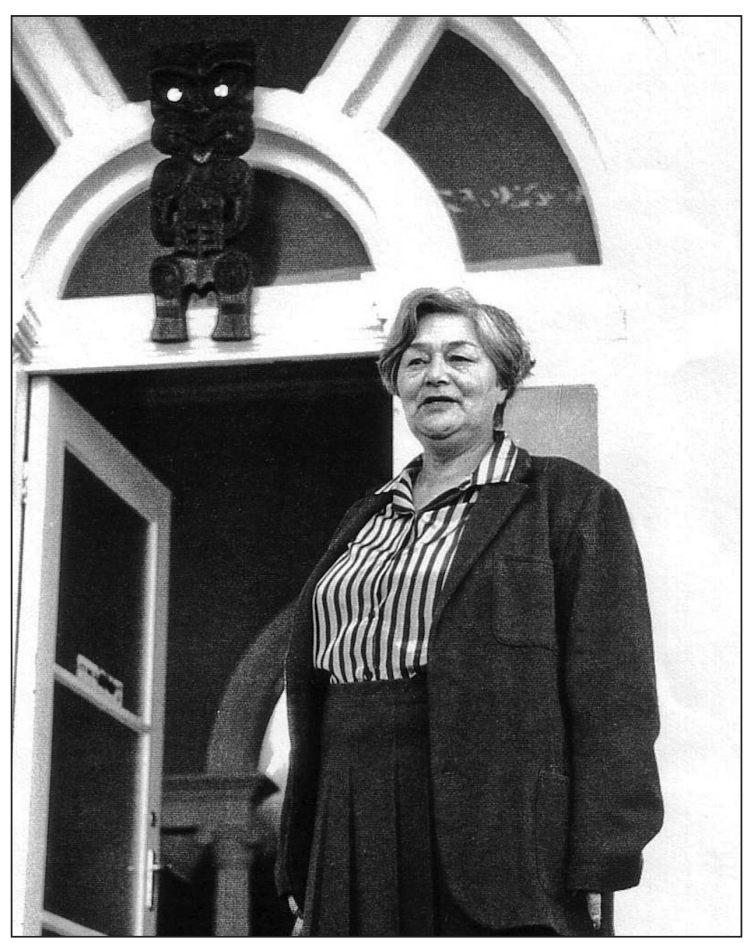

Figure 1. Betty as viewers saw her in the Television New Zealand documentary, Give Me a Love, produced by William (Bill) Saunders, August 1986. She is standing outside the entrance to Arohanui Trust, Auckland. Private collection of Wark whānau.

Elizabeth (Betty) Wark, QSM, was born on 6 June 1924 at Omanaia, Hokianga, Northland, Aotearoa/New Zealand. She had whakapapa 'genealogy' connections to both Māori and Pākehā 'New Zealander of European descent' although she identified more as Māori. Her iwi ‘tribe' was Ngā Puhi. 
Betty married twice and had five sons: Brian, Danny, Conrad, Robert and Gary. During her life time she saw the birth of ten grandchildren and five great grandchildren. Whāea Betty or Ma Betty, as she was more commonly known, spent a large part of her adult life providing assistance to the disadvantaged in Auckland through a variety of grassroots initiatives and political activism.

\section{BETTY'S EARLY LIFE, 1924-1944}

Betty Wark knew very little about the circumstances of her birth: "I was told that I was born under a plum tree at Omanaia at around $9.00 \mathrm{pm}$ and that a big black dog happened to come along and was my mother's sole support throughout her labour" (Connor 2006: 115). As a child, Betty did not know the identity of either of her parents. Her mother was Māori of Ngā Puhi descent and she later learned that her father was both Māori and Pākehā but tended to identify as Pākehā. They were not married and Betty's mum was turned out of the house for falling pregnant.

Betty was raised with several Māori families as a tamaiti whāngai 'foster child' and was known by the name of one of her initial foster familes: Te Wake. Betty was unclear as to her mother's exact relationship to the Te Wake whänau 'family' but there must have been one for her to be particularly fostered by them. Fostering was a customary extension of the Māori practice of whanaungatanga 'extended family' and communal living, and was a relatively common occurrence for many Māori families (Metge 1995). Betty spoke of having an overwhelming desire, as a child, to meet her biological parents around whom she had created an elaborate fantasy. She did not meet them until her early 20s and she was not familiar with her ancestral whakapapa until her mid-life.

Betty's sense of dislocation as a child reveals both an individual personal and a generational cultural loss of identity. Born in an era when the government of Aotearoa/New Zealand encouraged the assimilation of Māori and Pākehā, it was also a time when remnants of the commonly held belief that Māori were doomed to extinction still existed (Ballara 1986, Belich 2001, Sorrenson 1977). Belich wrote: "As the twentieth century opened, most Pakeha and some Māori believed that the Māori people were destined for extinction. At best, they were thought to face complete assimilation" (Belich 2001: 191).

As the 20th century progressed Māori were acquiring immunity from European introduced diseases and the Māori population began to increase, although Māori infant mortality rates remained high (King 2003: 325). With the advent of the First World War (1914-1918) Māori leaders such as Maui Pomare, Te Rangi Hiroa and Apirana Ngata encouraged Māori men to enlist believing Māori had earned the right to equal citizenship status with Pākehā (King 2003: 333). Māori ex-servicemen were hopeful that the 
conditions of wartime equality with Pākehā soldiers would continue. But King (2003: 334) noted that this was not the case. Legislation forbade the sale of alcohol to Māori and they were excluded from financial assistance for farm development and few were eligible for rehabilitation assistance. The discourses of assimilation underpinned by Governor Hobson's much quoted phrase, "He iwi tahi tatou-we are one people" (Orange 1990: 21) at the signing of the Treaty of Waitangi on 4 February 1840 had not translated into equality between Māori and Pākehā. Assimilation signified mono-culturalism and legalised imperialism where Māori were to become brown Pākehā if they were to survive.

Growing up in such a divided world it was understandable that Betty's sense of cultural identity was fragmented. She knew she was of Māori descent but, as a child, her knowledge of things Māori was limited. Although she grew up in the predominantly Māori area of the Hokianga, and was exposed to Māori language and culture in a peripheral way through such practices as listening to and repeating karakia 'prayers' in Māori and attending functions at local marae 'meeting place', the dominant culture of her childhood was European.

Betty's experiences of cultural alienation were, however, not necessarily typical for Māori who were raised in the Hokianga district in the early 20th century. Prominent Māori leader Dame Whina Cooper (1895-1994) who was born in 1895, 29 years earlier than Betty, was raised in a family with strong Māori values. Whina was profoundly influenced by her father Heremia Te Wake, who was a community leader in the settlement of Te Karaka in the northern Hokianga. Heremia was also a catechist for the Catholic Church which was established in the district in 1838 (King 1983). Whina Cooper "was a woman of extraordinary vision and energy who accomplished a great deal: the introduction of land development into the Hokianga, the launching of the Māori Women's Welfare League, the building of Te Unga Waka Catholic Marae in Auckland and the organisation of the Māori Land March" (King 1983: 7).

Betty's early childhood was not immersed in tikanga Māori 'Māori cultural practices' as was the childhood of Whina Cooper, even though one of Betty's initial foster families was connected to Whina. Betty's memories of her early childhood with the Te Wake whänau were patchy and fragmented; however, she was eventually taken in by Hau Te Wake, older brother of Dame Whina:

Hau Te Wake was a very strict man and he had very little to do with the children because he was out in the forest most of the time. We only ever saw him at night. I don't know how I came to live in the Waipoua Forest with Hau Te Wake. There was a stream at the bottom of the garden. We had to wash there every night. Bread was made in a camp oven, buried. You dug a part by the 
open fire place and you put charcoal on the top. We often would go out to the beach and put up a tent and collect kaimoana 'seafood', such as mussels and pāua [Halliotis] and then they were dried in the chimney back at the house.

Betty's sense of identity as Māori when she was growing up was complex. While she was exposed to Māori culture and language and was fostered by several influential Māori families she nevertheless felt disconnected from her Māori whakapapa. This could have been, in part, because of the kind of racism which viewed persons of mixed origin in negative ways. Betty was frequently called "half-caste" and so felt she was neither Māori or Pākehā. These epithets she heard as a child were both negative and confusing. Then too she was frequently tormented with racist remarks as a Māori which made her ashamed of her Māori heritage.

The label "illegitimate" further compounded her sense of not belonging and being different. She was often called "bastard" and "no-good Māori bastard", and in her child's mind she associated being Māori as being bad. Her mother, she was told, was bad, and so, too, was she. Not all of her foster families were kind and attentive. Betty was subjected to emotional, physical and sexual abuse as she grew up. As with all children living in an abusive situation, Betty was intrinsically less powerful than the adults who were entrusted with her care. She was not in a position where she could exercise choice and leave the situation. "I didn't belong and I had no identity", is how she described her feelings of alienation during this time.

Betty's sense of Māori identity and connection to her whakapapa came about through an accumulation of learning akin to an apprenticeship. She had to learn about the history and traditions of her people from the place of an outsider. It might be inferred, however, that she had always had a deep emotional and spiritual connection to the land and to her tupuna 'ancestors'. As a little girl she would retreat to what she termed her secret maunga 'mountain' and lie in hidden little crevices until she felt revitalised. Reflecting back to that time she talked of being "guided" to experience the wairua 'spiritualty' of the earth, of Papatūannuku 'Earth Mother'. Tapping into the spiritual world is an inevitable aspect of acquiring Māori identity. However, during the colonisation period of Aotearoa/New Zealand, Christianisation was generally intolerant of Māori spirituality and consequently many aspects of Māori spirituality were either suppressed or lost (Ward 1978).

Catholicism was particularly deeply rooted in Northland. It was there that many of the first Irish Catholic settlers to New Zealand made their home (King 1997). In January 1838, the Frenchman Jean-Baptiste Pompallier arrived in the Hokianga as a young bishop, and many Māori were converted to Catholicism. Māori Catholic leaders, such as Heremia Te Wake, father of 
Dame Whina Cooper and part of the whanau in which Betty was fostered as a child, kept the faith alive by instructing children in the beliefs and prayers of the Church. In 1886 Father John Becker who was known as Pa Hoani arrived. He was primarily concerned with spiritual matters and did not attempt to interfere with the specifically Māori aspects of the community in which he became an accepted member (King 1983). A member of the order of Saint Joseph's Foreign Missionary Society, generally referred to as the Mill Hills, Becker and later Mill Hill priests became proficient in Māori language and lived with and identified with their Māori congregations (King 1997).

By the time Betty was born in 1924, Catholicism was an integral element of māoritanga 'Māori ways of thinking and acting' in the Hokianga region:

I'm Māori and I'm Catholic. In my early years it was the Mill Hill priests who were the main influence on my faith but it was the nuns at Saint Joseph's who were my role models. I used to be quite emotional. If I did any wrong or thought anything wrong, I'd race to the chapel to be forgiven! I learned the answering of the mass in Latin. I tried my best to please them - to be a good Catholic.

Although Betty's early childhood experiences of what it meant to be Māori were contradictory and mostly negative, these experiences were contested and challenged when she won a scholarship and became a pupil at Saint Joseph's Māori Girls' College in Napier in 1938. Betty's experiences of Saint Joseph's were positive and affirming. For the first time in her life she felt safe and was able to join in the frivolities of youth with the other girls at the school. The nuns nurtured her and gave her a new sense of identity. She reminisced that they taught her that "being Maori was something to be proud of and they taught me that all children are pure in the eyes of God".

Mãoritanga, for Betty, meant feeling connected to other Māori. It meant feeling complete and this is how she felt at Saint Joseph's. The irony of such an assertion is, however, that the Māori boarding schools of the era in which Betty attended (1938-1941) have been highly criticised for undermining a Māori cultural identity by promoting a policy of assimilation (Simon 1998). Such criticisms are well-founded as an examination of the original motivation for establishing the Church boarding schools reveals the "civilising and assimilating mission" that underpinned them was to "ensure regular attendance and Christian habits" (Barrington and Beaglehole 1974: 43-45).

Nevertheless, Betty enjoyed the special character of Saint Joseph's Māori Girls' College and she enjoyed meeting other Māori Catholic girls from different parts of the country: 
There would have been about 90 young girls from all parts of New Zealand, from the South Island, the East Coast, up North. I made some really good friends during my four years at Saint Joseph's. I wasn't what you would call a bright scholar but I enjoyed being down there because I got a lot of loving from the nuns. They were very good to me and really not having an actual family they became my family.

Betty's sense of belonging at Saint Joseph's Māori Girls' College and the love she felt for the nuns that cared for her can in part explain the apparent contradiction between the development of her mäoritanga within the context of a post-colonial schooling system that sought to assimilate Māori into the dominant Pākehā culture. In Betty's case leaving an abusive situation for the safety of St Joseph's gave her the opportunity to grow and find a new sense of identity. The nuns seemed to have allowed space for their Māori pupils to affirm their Māori culture within the confines of a curriculum that actively suppressed it. Certainly, Betty felt affirmed as Māori even though Māori language and Māori tikanga 'culture' were not taught in any depth at the school during the period Betty attended. Nevertheless, it was at Saint Joseph's that Betty realised she could identify as both Māori and Pākehā and that she could move between two worlds. Betty credited the nuns at Saint Joseph's with giving her a strong moral base and pride in herself as a Māori Catholic woman: "The nuns were all strong women and I've found a lot of women that have been to Catholic colleges are very strong women. They had a basis for a good life - they were given a good foundation". ${ }^{2}$

At the end of 1941 Betty was 17 years old. The Second World War had begun and it was a time to leave school and find a job. Betty recalled: "When I left school, Sister Crescentia got me a job at Wairoa Hospital. It was the beginning of the war and you became a nurse or a teacher or something like that." Betty entered the workforce at a time when the war was modifying what was appropriate work for women. Industrial conscription or "man-power" was introduced by regulation in 1942 and initially covered all women born in 1922 and 1923 (Montgomerie 1992). Born in 1924, Betty was not eligible for registration at this time, although by the end of the war she was. Sister Crescentia, however, pre-empted the National Service Department by securing Betty a job in nursing which encompassed both the patriotic narrative of serving one's country and the domestic narrative of feminine self-sacrifice. Betty was inducted into nursing in 1942:

I did six months nurse training at Wairoa Hospital but I didn't complete my training. I was quite good at the theory but I wasn't very good at the practical. I didn't like to see people hurt. If I saw anybody badly injured I'd pass out. And I didn't like all the dirty jobs and all the cleaning. I didn't like giving 
enemas and cleaning bed pans. Anyway I left nursing and got a job as a housekeeper to a Doctor Harvey.

Betty worked for the Harveys for about one year before going to work for another family, the McFarlanes, in Napier. On her evenings off Betty would attend dances and, like many other young New Zealand women, she found the American servicemen attentive and exciting. She met Charles Turner, an American marine, at a dance. He was her first love and she relished every moment with him and the escape he represented from the daily drudgery of her work. Soon after meeting Charles she left her job with the McFarlanes and went nurse aiding at the Pukeora Sanatorium in Waipukurau so he could visit her more easily. Betty later moved to Wellington and took a job with the Army in Base Records. Charles continued to court Betty and they became engaged, and, as was frequently the case with romances during the war, in 1944 Betty became pregnant.

\section{MARRIAGE AND MOTHERHOOD 1945-1976}

The prevalent gender ideology in Aotearoa/New Zealand in the 1940s condemned and punished women's sexual activity except within the institution of marriage, which was a deeply embedded desire for the majority of women (Matthews 1984). Yet, during the Second World War, many New Zealand women became pregnant to American servicemen. Some married their lovers, some did not (Bioletti 1989: 77). Charles and Betty had plans to wed and Betty was looking forward to a new life with Charles in the United States. Tragically, before they married, Charles was killed in action at the battle of Guadalcanal. Over 50 years later Betty still found it very difficult to talk about this time of intense sorrow.

When Betty found herself alone and pregnant she was frightened and felt totally unprepared for the responsibility of motherhood. She did, however, receive some support from the U.S. Armed Forces They helped her with clothes for the baby and wrote a letter to Mary, one of her foster mothers.

I was scared to contact Mary but the army contacted her and I got a telegram saying bring the baby home. The army paid for my fare back - picked me up and put me on the train, gave me some money and sent me up north.

Betty left her son Brian with Mary and went to Auckland in search of work. She held a variety of jobs including a ward's maid at Auckland Hospital, a cook, a waitress and filing at Farmer's Trading Company.

I don't know whether I was very happy because as a rural person coming to the city, I found it very hard. I guess I understand why these young people 
who come from the rural areas find it hard to live in the city. I didn't find it exciting. I found it a little frightening.

After the war the urbanisation of Māori increased as many Māori moved into small towns and cities to find work. Betty was part of this influx of Māori urbanisation. In 1945 there were around 4,903 Māori living in Auckland and by 1951 , there were 7,621 . The process of urbanisation continued to intensify and by the 1960s, Māori had become a predominantly urban people (King 1981: 283).

During this time she had her second significant relationship, with Henry Smith, an Englishman. He wanted to marry Betty but she refused and he returned to England. Henry was the father of Betty's second son, Danny, who was born in 1948. He was fostered in Waihi within the extended family. Betty lived in Waihi for two years following Danny's birth and then returned to Auckland in 1950. It was then that she met and married a Canadian in 1952. When Betty decided not to emigrate to Canada, her husband returned to Canada alone, leaving his wife and their infant son, Conrad, behind. Betty was entitled to a deserted wife's benefit so she was able to keep baby Conrad with her. She found rooms in a boarding house in Grafton, an inner city suburb of Auckland, and set about making a home for herself and her son. While living in Grafton, Betty met Jim Wark who would become her second husband and the father of two further sons. Robert was born in 1959 and Gary in 1961. Jim Wark provided the security Betty craved and together they created the home and family Betty had yearned for all her life. After a number of moves they settled in Herne Bay, an inner city suburb of Auckland, in the 1970s.

In the early days of their relationship Betty and Jim were happy together, but by her late thirties Betty was growing more into what she termed "her own person". She became more involved with her community work and there was an inevitable conflict between her family life and her public life. Betty explained:

Jim was a good man. We stayed together as a family unit until I found my Māoriness. I got involved in the Māori Community Centre during the 1960s and the time of the urban renewal. Jim didn't understand what was happening, although he was very sympathetic towards Māori and knew a lot about Māori history.

Betty termed her community work and activism, her "heart politics". It was a term which represented her courage in overcoming her fears and self-doubt. It also represented her involvement in community grassroots initiatives and the feelings of connectedness she felt with the people and the causes she became involved with. Her strength and commitment came from 
the heart. Betty became immersed in a variety of community projects such as the Freemans Bay Advisory Committee which assisted with temporary accommodation for the working class tenants who had lost their homes to urban renewal, a process that demolished old, run-down homes in the Freemans Bay area and replaced them with council flats. She was also a founding member of the Tenants' Protection Association formed in 1972.

As Betty's heart politics evolved so, too, did her identity as Māori. She was an active member of the Ponsonby branch of the Māori Women's Welfare League and it was here she found a deep connection of spirit and mind. Although not necessarily connected by kinship she felt a real sense of whänau. She developed very deep and special bonds with many of the kuia 'female elders' at the centre.

I used to go up to a place in St Marys Bay Road where the meetings were held and there were a lot of beautiful elderly women there: Mrs Edmonds, Mrs Tai, Mrs Ruby Smith. They kind of supported me, taught me, and they knew where I was coming from and they were very, very supportive in teaching me, not so much to speak Māori but to understand what Māori was all about.

Betty found a strong sense of Māori community at the Māori Community Centre in Ponsonby and with the Māori Women's Welfare League and the Māori Catholic Marae, Te Unga Waka at Epsom. ${ }^{3}$ Hoani Waititi Marae and other urban marae initiatives also marked the starting point for a new wave of Māori development which Betty and women such as Letty Brown, a prominent Māori woman leader in West Auckland, were involved in. Letty's vision was to develop a Māori community where tamariki 'children' could grow up together and feel part of a Māori social order and Māori education initiatives such as kohanga reo 'language nests' would have a place so Māori children could be taught their own language and culture (Harris 2002: 115).

Betty also became interested in prisoners' rights and prison reform and the work of Ana Tia, a well-known Māori woman who tutored prisoners in kapa haka 'Māori cultural performance'.

In 1974 Betty helped set up Arohanui Incorporated, a community-based organisation which provided housing and assistance to young persons referred from the courts, prisons, Social Welfare and other sources. In 1976 Betty left her marital home and moved into one of the Arohanui Trust hostels as a housemother, though she maintained an enduring friendship with Jim Wark for the remainder of her life. When Betty left the marriage, her three younger sons were no longer overly dependent on her and Jim. Conrad was aged twenty-four and had already left home; Robert and Gary were aged seventeen and fifteen respectively. Betty maintained very close contact with Jim and the boys, and her youngest son Gary eventually joined his mother in her work at Arohanui. 


\section{AROHANUI AND PUBLIC RECOGNITION 1976-2001}

Arohanui was formed as a community response to a community problem. The main focus for Betty and the other trustees and workers at Arohanui was to maintain a positive environment for the residents - to create a home. One of Betty's closet work colleagues during the 1970s and 1980s was Fred Ellis. Fred and Betty would patrol the streets during the winter nights taking creamed mussel soup and scones to "street kids", urging them to make contact with Arohanui. Many would and were either reunited with whanau 'family' or alternative accommodation was found for them.

As Arohanui grew and began applying for government funding, the Trust also began offering formalised programmes such as literacy and numeracy programmes. In addition Arohanui strengthened its Māori culture and language programmes and introduced some innovative health and exercise programmes which used Eastern martial arts and Māori weaponry training. Betty maintained an avid interest in alternative learning and ways to turn Arohanui residents on to education. She also maintained an interest in reviving traditional Māori models of teaching, and learning about new developments within Māoridom. Betty's openness to exploring and trialling alternative education also extended to investigating alternative treatments for drug and alcohol addiction. Over the years a large proportion of Arohanui's residents had problems with addiction and the abuse of solvents, drugs and alcohol. Various programmes were investigated to assist the residents including the Scientology programme, Narcanon, which appeared to offer some practical and productive solutions.

Betty's growing media profile publicised her work and widened her networks, and she became skilled at gaining publicity for causes dear to her heart politics. In February 1976 there was wide media coverage of the occupation of Tole Street Reserve in Ponsonby by tent dwellers, a protest organised by Betty, which succeeded in dramatising housing issues and securing further hostel accommodation. Housing the homeless and utilising buildings to their full extent became a passion:

I was very interested in what the Auckland City Council was doing as far as housing, jobs and things like that and I'd frequent a lot of their monthly meetings and I got pretty well known down there for what I did. I was complaining about the houses in Freemans Bay where people paid high rents to absent landlords.

Betty's commitment to ordinary working class people on lower and moderate incomes and her involvement in the local affairs of the Freemans Bay and Ponsonby communities led her to stand for election on the Auckland City Council. Betty served on the Auckland City Council from 1986 to 1989. 
Betty's main area of strength was seen as working with people and housing issues:

Betty was very active on housing issues, not simply in relation to ACC issues, but to central government issues as well, on housing policy and she had built a reputation as a person who was not a theoretician but as somebody who worked consistently over a long period of time providing real assistance to people. So it was that kind of mana that she developed in the community based on experience. Her forte was working with people. She was consistently there assisting people and that was one of her major qualities (Bruce Hucker, pers. comm.).

Betty was 63 years old when she stood for Council. At a time when most of her peers were thinking about retirement she had taken on another challenge. She was never completely comfortable working within the established structures and restraints of Council and often felt isolated as the only Māori woman on the Council at the time.

$$
* * *
$$

The historical and social context of Betty's evolving sense of political activism and her "heart politics" was the Māori Renaissance movement of the 1970s which brought about a dramatic revival of Māori culture. Many of the initiatives came from radical urban groups such as those Betty was involved in. Pressure groups such as the Tenants' Protection Association, the People's Union and Freemans Bay Advisory Committee pressed for equality between Māori and Pākehā at all levels of public policy. For Māori involved in such groups, one of the outcomes was an assertion of Māori identity and pride after experiencing the debilitating effects of post-war Māori urban migration. The Pākehā-dominated, mono-cultural society was being challenged, and Māori concerns around the Treaty of Waitangi and loss of land were brought to the forefront of New Zealand's political environment.

For Betty, there were a number of powerful and frequently contradictory forces which helped forge her identity as Māori. Throughout childhood she had experienced considerable shame and alienation and what Scheff (1994) refers to as the shame/pride loop in terms of her cultural sense of self and her emotional self. She was however, strong enough to transcend that place of powerlessness and vulnerability and she was able to contest and overcome the negative stereotyping and spurious criticisms she had been subjected to. Indeed, Betty not only survived these difficulties, she triumphed over them.

When reflecting upon what drove Betty to undertake her community work with such passion and vigour it is important to remember that she began her life from a place that served to marginalise and disempower her. She not only 
survived the persistent undermining of her cultural identity and the racism she experienced, she also survived physical, mental, emotional and sexual abuse and a childhood virtually devoid of stability and love. As is very common with survivors of abuse there was an enormous amount of self-blame. "I would wonder what I had done to deserve being treated the way I was. I never felt I was a good person". The survivor narrative that permeates Betty's life story, together with the driving force of anger, provides an insight into what motivated and drove her to commit so much of her personal energy to the community work which brought her public acclaim. A woman who wished to remain anonymous and had worked with Betty during the 1970s gives witness to this anger in the following description: "She was consumed with rage - she was angry - manipulative and very strong. She seemed to have a psychic or spiritual awareness and knew how to control a situation. She knew her power."

Her rage fuelled an acute sense of social injustice. She was motivated by a politics straight from the heart. For Betty, the dynamic force of anger was transformative; not only for herself but for those young people who were cared for at Arohanui. She came to recognise how anger motivated her and she recognised the young people in her care shared similar hurts:

Looking back at my life I had a hard life but if I hadn't gone through that I wouldn't be surviving today. So it has balanced off. It has balanced off. I still get a bit sad about some of the things but I don't use it as a crutch. I don't use it as a crutch. And that's why with the young people at Arohanui I know how they feel because a lot of them have been through exactly the same kind of thing.

Betty' story conforms to the parable of the triumph of the human soul in the face of adversity. She was a woman who endured appalling hardship and abuse as a child yet she was able to draw on these experiences in order to help transform the lives of others.

In January 1990, Pat Booth, of North and South magazine wrote a series on prominent figures termed "Living Treasures" and featured Betty Wark. The metaphor of a living treasure was an apt one for someone as remarkable as Betty Wark. She was indeed a taonga 'treasure' to the hundreds of rangatahi 'youth' she offered refuge to under the umbrella of the Arohanui Trust. Betty, although well used to accolades, was, nevertheless, modest about her work and accomplishments. To be described as a "living treasure" was something of an anathema to her. She preferred the focus to be on her mahi 'work' and not on her personally. While Betty wore the accolade of "Living Treasure" with modesty and humility, others felt the honour was just and fitting. Dame Catherine Tizard who was Mayor of Auckland at the time Betty was on the Auckland City Council told me: 
She certainly made a contribution and always voted along the lines of her conscience. She did try to bring a Māori perspective to Council long before there were any Māori advisory committees and she forced us to see things from a Māori perspective. Thank God for people like Betty Wark who do what they can do without expecting reward and without worrying about what other people think about them and the way they do it-she just got on and did it (pers. comm. Dame Catherine Tizard, 3 September 1996).

Of all the awards Betty received she was particularly humbled by the award of the Queen's Service Medal in 1986; the Investiture of which was awarded in person by Her Majesty Queen Elizabeth II who was touring New Zealand at the time. In 1996 Betty won top honours in the Trustees Executors Senior Achiever's Award. The award recognised 50 years of voluntary services to the community. The award was sponsored by the Retired Persons' Association. When interviewed by the New Zealand Herald on 2 October 1996, Betty jokingly said she regretted she could not qualify for membership of the organisation behind the award: "Retirement, what's that?" she asked.

Retirement eluded Betty. The work she began in her thirties and forties in response to seeing those homeless young men in Freemans Bay took her in a direction that would eventually become her path or vocation - her "soul work". The concept of "soul work" referred to meaningful occupation or mission into which we are beckoned. Betty believed she had been "called" to her work, much as the nuns at St Josephs had been called to their vocation as Sisters of Our Lady of the Missions. "Soul work" expresses our unique essence and embraces the full dimension of who we are and what we most cherish. The notion of retirement becomes redundant, for "soul work" in some form or another is what we can do until we are very old (Batten 2000: 24).

Betty was diagnosed with lung cancer in 2000 shortly after her 76th birthday in June 2000. She continued to carry out her life's "soul work" until she was too frail to do so. Betty Wark died peacefully at $12.40 \mathrm{am}$, Thursday, 16 May 2001 in her 78th year surrounded by her whanau. After her death Betty lay in state at Ngā Whare Waatea Marae at Mangere where a Requiem Mass was held for her on Friday 17 May. On Saturday 18 May, as she had requested, her body was taken back to Motuti Marae in the Hokianga to await burial in her papakainga 'home base'. She wanted to return to the Hokianga, where her whakapapa connected her. She wanted to make the journey Home.

\section{ACKNOWLEDGEMENTS}

I would like to acknowledge the late Betty Wark for sharing her inspiring and courageous story. I would also like to thank Phyllis Herda for her helpful comments and critical engagement with this article. 


\title{
NOTES
}

1. At the time I was contemplating putting together a proposal for a $\mathrm{PhD}$ (Connor 2006) on Māori women's biography, Betty Wark advertised for someone to write her life story. Betty's community work in Central Auckland and what actually motivated her to do this work provided ample material to consider her as a potential subject for a biographical research project. I made contact with Betty and discussed the idea of developing a research proposal that incorporated both an academic and creative component which would be able to accommodate her biography together with the research and academic requirements of a doctoral thesis. Betty was very open to this approach and once the proposal was approved work on the biography began. Throughout the writing of her biography, each chapter was returned to Betty for comment, and authorisation. The interviews took place during 1996 and all quotations attributed to Betty are from these interviews. Betty's portrait is based on these interviews and my doctoral thesis (Connor 2006).

2. See Nathan Matthews (2007) whose research on Hato Paora College in Feilding explores how leadership and strong male role models were present for Mãori boys who have attended Catholic boarding schools.

3. Freemans Bay and Ponsonby are contiguous suburbs in inner city Auckland. Epsom is also a suburb of inner city Auckland and is located on the eastern side of the city.

\begin{abstract}
Whāea or "Ma" Betty Wark was a Māori woman who was actively involved with community-based organisations from the 1950 s until her death in May 2001. She was particularly well-known as being one of the founders of Arohanui Incorporated which was established in 1976. Its main purpose was to provide accommodation for young homeless Māori and others in need.
\end{abstract}

Keywords: Betty Wark, Māori women's biography, Arohanui Incorporated, Catholicism

Author contact address: Dr Helene Connor, Unitec, 1 Carrington Road, Mount Albert, Auckland 1025, New Zealand. Email: hconnor@unitec.ac.nz 